\title{
Multiple Acyl-CoA Dehydrogenase Deficiency (Glutaric Aciduria Type II) with Transient Hypersarcosinemia and Sarcosinuria; Possible Inherited Deficiency of an Electron Transfer Flavoprotein
}

\author{
STEPHEN I. GOODMAN, EDWARD R. B. MCCABE, PAUL V. FENNESSEY, AND JOHN W. MACE \\ Department of Pediatrics, University of Colorado Medical Center, Denver, Colorado and Department of Pediatrics (J. \\ W. M.) Loma Linda University Medical Center, Loma Linda, California, USA
}

\begin{abstract}
Summary
When amino acids were infused at a rate of $4 \mathrm{~g} / \mathrm{kg} / \mathrm{day}$, an infant with hypoglycemia, metabolic acidemia and chronic regurgitation showed hypersarcosinemia and excreted abnormal amounts of sarcosine, isovalerylglycine, isobutyrylglycine, $\alpha$-methylbutyrylglycine, and $\beta$-hydroxyisovaleric, glutaric, $\alpha$-hydroxyglutaric, methylsuccinic, and $\alpha$-hydroxyisobutyric acids in urine. On all other occasions, when protein intake was lower and lipid intake higher, urine organic acids were dominated by methylsuccinic, ethylmalonic, and $\alpha$-hydroxyglutaric acids, and hypersarcosinemia was absent. Autopsy showed severe fatty changes in liver, kidneys, and skeletal muscle. A previous female sibling had died with similar autopsy findings at $\mathbf{4}$ days of age. While activity of glutarylCoA dehydrogenase was completely deficient in liver and almost completely so in kidney, it was normal in cultured fibroblasts in the presence of flavin adenine dinucleotide (FAD) and only marginally low in its absence. Incorporation of $\mathrm{D}-\left(2-{ }^{14} \mathrm{C}\right)$ riboflavin into flavin mononucleotides (FMN) and FAD by kidney tissue was normal.
\end{abstract}

The authors conclude that this disorder is not due to generalized deficiency of glutaryl-CoA dehydrogenase or to a defect in FAD synthesis. The amino and organic acid abnormalities noted are most consistent with a defect in the flavoprotein which transfers electrons from the FAD of sarcosine and acyl-CoA dehydrogenases into the respiratory chain, although a defect in intercompartmental transfer of C4-5 acyl CoA esters across cell membranes is not excluded.

The variability of the organic aciduria, which possibly reflects changes in protein and fat intake, suggests that a previous name for this disorder, i.e., glutaric aciduria type II, is inappropriate and should be replaced, perhaps by "multiple acyl-CoA dehydrogenase deficiency."

\section{Speculation}

What appears to be simultaneous deficiency of several acyl-CoA dehydrogenases may be caused by a number of different primary gene defects; the presence of hypersarcosinemia and/or sarcosinuria may delineate a subtype due to deficiency of an electron carrier flavoprotein. Further, the presence of organic aciduria may define a form of hypersarcosinemia more likely to be associated with phenotypic abnormalities than isolated deficiency of the sarcosine dehydrogenase apoenzyme.

Glutaric aciduria type II is the name given to a disorder, to date described in only one male child, in which severe metabolic acidemia, hypoglycemia, and death in early infancy was associated with the urinary excretion of large amounts of glutaric acid and smaller, albeit also abnormal, quantities of $\alpha$-hydroxyglutaric, ethylmalonic, lactic, isobutyric, isovaleric, and $\alpha$-methylbutyric acids. An older male sibling had died of a clinically similar disorder. Intact fibroblasts from the patient metabolized valine, isoleucine, leucine, and glutaric acid at reduced rates, while oxidation of pyruvic acid was normal. As these findings were consistent with simultaneous deficiency of several FAD-containing enzymes, an abnormality of either FAD synthesis or the electron transport chain was suggested as the possible site of a primary gene defect (24).

The type II designation was meant to distinguish this condition from glutaric aciduria, a condition which is associated with a movement disorder (dystonia, athetosis, etc.), increased excretion of glutaric, glutaconic, and $\beta$-hydroxyglutaric acids, and chronic degeneration of the caudate and putamen $(13,15,20)$, and which is due to recessively inherited deficiency of glutaryl-CoA dehydrogenase (11).

The purpose of this paper is to report biochemical studies in a child with the organic aciduria of glutaric aciduria type II in whom transient hypersarcosinemia and sarcosinuria were also detected. The results presented indicate that the disorder is not due to generalized deficiency of glutaryl-CoA dehydrogenase and probably not to a block in FAD synthesis. Although the specific cause of the disease remains obscure, the results are most consistent with a defect of the electron transfer flavoprotein which transfers electrons from the FAD of sarcosine and acyl-CoA dehydrogenases into the respiratory chain.

\section{CASE REPORT}

The patient, a full term male, weighed $3.6 \mathrm{~kg}$ on delivery by $\mathrm{C}$ section. His only sibling, a girl, had been born 1 yr earlier after a difficult labor, had appeared normal at birth (Apgar at $5 \mathrm{~min}=$ 10 ), but became lethargic in hospital and died suddenly at 4 days of age. Autopsy showed cerebral edema and diffuse fatty infiltration of hepatic parenchymal cells, and the parents were told that the child had died of Reye's syndrome.

The boy appeared normal at $10 \mathrm{hr}$ of age, but $24 \mathrm{hr}$ later was feeding poorly and had become lethargic, hypotonic and acidemic (serum bicarbonate $=10 \mathrm{mEq} /$ liter). He was transferred to Loma Linda Medical Center where admission examination showed tachypnea with grunting respirations, hypotonia, and slight hepatomegaly. A foul odor was noted on the 3 rd day of life, but was transient and not investigated further. Early lab values included; hemoglobin $11.8 \mathrm{~g} / \mathrm{dl}$, white blood cell count $15,300 / \mathrm{mm}^{3}$ with $79 \%$ segmental polymorphonuclear leukocytes and $21 \%$ lymphocytes, platelets $273,000 / \mathrm{mm}^{3}$, glucose $9 \mathrm{mg} / \mathrm{dl}$, bilirubin $5.5 \mathrm{mg} / \mathrm{dl}$ 
(direct 0.2 ), and calcium $1.68 \mathrm{mM}$. Chest X-ray and cerebrospinal fluid were normal. The initial impression was sepsis and, after appropriate cultures had been drawn, glucose and antibiotics (ampicillin and kanamycin) were administered iv. All cultures were negative. Lethargy, poor feeding with regurgitation, and failure to gain weight even on gavage feedings persisted during the next 2 wk; blood ammonia measured during this period was $56 \mu \mathrm{g} / \mathrm{dl}$. A trial of intravenous amino acids (Freamine II. $4 \mathrm{~g}$ amino acids $/ \mathrm{kg} /$ day) was begun on the 17 th day of life; within 12 $\mathrm{hr}$ compensated metabolic acidemia (serum bicarbonate $=15$ $\mathrm{mEq} / \mathrm{liter}$ ) and an odor of sweaty feet had become obvious and urine organic acid chromatography was ordered to confirm a diagnosis of isovaleric acidemia. The chromatogram shown in Figure 1 (top) was obtained, and on this basis, the probable diagnosis was changed to glutaric aciduria type II.

Feeding with a low-protein diet did not alter the clinical course. Poor weight gain and chronic regurgitation persisted and he died at the age of 5 months, with autopsy showing severe fatty changes in the liver, kidneys, and skeletal and cardiac muscle. No changes were noted in the basal ganglia (13). (The amount of protein given the child after diagnosis is in question; the diet prescribed contained $1.2-1.4 \mathrm{~g} / \mathrm{kg} /$ day but the amount given may have been half that. Several of the clinical and laboratory findings during the last admission (edema, total protein $=4.0 \mathrm{~g} / \mathrm{dl}$, hematocrit $=24.8$ ) were consistent with protein malnutrition, and the contribution this may have made to the anatomic and biochemical findings in tissues cannot be evaluated.)

\section{MATERIALS AND METHODS}

Autopsy was performed $3 \mathrm{hr}$ after death; samples of liver and kidney were frozen immediately and maintained at $-20^{\circ}$ until assayed for enzyme activity. Urine and serum samples were maintained at $-20^{\circ}$ before analysis for amino and organic acids.

Urine and serum amino acids were measured on a Beckman model $121 \mathrm{M}$ amino acid analyzer using lithium citrate buffers. Urine organic acids were examined as described previously (10) and peaks were identified by combined gas chromatography-mass spectroscopy using an AEI MS-12 medium resolution instrument. Organic acids were quantitated by gas chromatography using appropriate internal and external standards to correct for extraction efficiency and size of injection.

Fibroblast culture was established from pinch-skin biopsy and the cells grown in minimum essential medium with Earle's salts containing $15 \%$ fetal bovine serum, non-essential amino acids, and antibiotics. Oxidation of glutaryl-CoA fibroblast sonicates was determined as previously described (11); assays were performed with and without added FAD.

Oxidation of glutaryl-CoA in frozen tissues was measured by a modification of a method described for use on isolated mitochondria (2). Tissue was homogenized and then sonicated in 9 volumes $0.02 \mathrm{M}$ potassium phosphate $\mathrm{pH} 7.5$ with $0.001 \mathrm{M}$ cysteine, and $0.1 \mathrm{ml}$ of the sonicate was incubated for $10 \mathrm{~min}$ at $37^{\circ}$ in a $1 \mathrm{ml}$ mixture containing $60 \mu$ mole potassium phosphate, $\mathrm{pH} \mathrm{7.5,0.1}$ $\mu$ mole cysteine, $0.1 \mu$ mole FAD, $1 \mu$ mole methylene blue, and (usually) $0.1 \mu$ mole $\left(1,5-{ }^{14} \mathrm{C}\right)$ glutaryl-CoA (specific activity, 1.6 $\mathrm{mCi} / \mathrm{mmole}$ ) (12). Reactions were stopped with $0.5 \mathrm{ml} 25 \%$ TCA and $\mathrm{CO}_{2}$ was trapped in $10 \% \mathrm{KOH}$ and counted in a Beckman LS-233 liquid scintillation counter. Assays were also performed on acetone-extracts of liver and on sonicates which had been dialyzed for $16 \mathrm{hr}$ at $4^{\circ}$ against homogenizing buffer. Glutamate dehydrogenase activity in liver was measured by a standard method (25).

To examine incorporation of riboflavin into FMN and FAD by kidney, tissue was homogenized in 4 volumes $0.15 \mathrm{M}$ potassium phosphate, $\mathrm{pH} 7.5$, and $0.2 \mathrm{ml}$ of the homogenate was incubated in the dark for $1 \mathrm{hr}$ at $45^{\circ}$ in a $1 \mathrm{ml}$ mixture containing $75 \mu$ mole potassium phosphate $\mathrm{pH} 7.5,1 \mu$ mole $\mathrm{MgCl}_{2}, 0.1 \mu$ mole $\mathrm{ZnSO}_{4}$, $1 \mu$ mole ATP, and $0.5 \mu \mathrm{Ci} \mathrm{D}-\left(2-{ }^{14} \mathrm{C}\right)$ riboflavin (specific activity 31 $\mathrm{mCi} / \mathrm{mmole}$; Amersham/Searle). Reactions were terminated by adding $2.4 \mathrm{ml}$ methanol which contained riboflavin, FMN and FAD (1.2 mg each). After mixing and centrifugation $(60,000 \times \mathrm{g}$ at $4^{\circ}$ for $30 \mathrm{~min}$ ), $250 \mu \mathrm{l}$ of the supernatant was applied to a $1 \times$ $14 \mathrm{~cm}$ column of DEAE-Sephadex A-25 resin and the flavins eluted with $1 \%$ ammonium sulfate. Pooled fractions of riboflavin, FMN, and FAD were lyophillized to dryness and counted (6).

\section{RESULTS}

\section{AMINO ACIDS}

Urine amino acids were normal for age on all occasions on which they were measured except at 19 days when, after 2 days of parenteral hyperalimentaion, a generalized aminoaciduria especially marked in glycine $(1.957 \mathrm{~g} / \mathrm{g}$ creatinine), methionine (1.602 $\mathrm{g} / \mathrm{g}$ creatinine $)$, and lysine $(0.829 \mathrm{~g} / \mathrm{g}$ creatinine $)$, and a peak with the elution and $570 / 440 \mathrm{~m} \mu$ absorbance ratio characteristics of sarcosine ( $1.148 \mathrm{~g} / \mathrm{g}$ creatinine) were observed. Serum amino acids were determined on four occasions (Table 1). They were not measured on day 19 , but 4 days later, when the child received 2 $\mathrm{g}$ amino acids $/ \mathrm{kg}$ iv, serum sarcosine was $0.140 \mu \mathrm{mole} / \mathrm{ml}$ (normal = not detected). On the other occasions, noted intake was entirely oral but severely restricted in protein, and hypersarcosinemia was not detected.

\section{ORGANIC ACIDS}

Table 2 shows the longitudinal excretion of the more prominent organic acids found in the urine. The chromatogram at 19 days, when iv amino acids approximated $4 \mathrm{~g} / \mathrm{kg}$, is shown in Figure 1 (top); the large abnormal peaks of isovalerylglycine and $\beta$-hydroxyisovaleric, glutaric and $\alpha$-hydroxyglutaric acids are apparent as are smaller, albeit also abnormal, peaks due to $\alpha$-hydroxyisobutyric acid, methylsuccinic acid, isobutyrylglycine, and $\alpha$-methylbutyrylglycine. Ethylmalonic acid was not detected at this time but, together with methylsuccinic and $\alpha$-hydroxyglutaric acids, was prominent in other samples, e.g., Figure 1 (bottom), when daily protein intake was less than $2 \mathrm{~g} / \mathrm{kg}$. Small amounts of lactic and adipic acids were observed only intermittently, and suberic and sebacic acids were never detected. Other organic acids not detected included glutaconic and $\beta$-hydroxyglutaric, which are usually seen in isolated deficiency of glutaryl-CoA dehydrogenase (29), and $\eta$-hexanoylglycine, which has been observed in ethylmalonic aciduria (33) and in Jamaican vomiting sickness (32).

Table 1. Serum amino acids $(\mu \mathrm{mole} / \mathrm{ml})$

\begin{tabular}{lccccc}
\hline \multicolumn{1}{c}{ Age (in days) } & 23 & 42 & 56 & 63 & Normal \\
\hline Taurine & 0.05 & 0.05 & 0.09 & 0.20 & $0.02-0.11$ \\
Aspartic acid & 0.04 & 0.03 & 0.04 & 0.12 & $0.01-0.02$ \\
Threonine & 0.21 & 0.11 & 0.13 & 0.23 & $0.17-0.23$ \\
Serine & 0.31 & 0.23 & 0.41 & 0.61 & $0.16-0.20$ \\
Glutamic acid & 0.65 & 0.64 & 0.26 & 0.65 & $0.06-0.21$ \\
Sarcosine & 0.14 & n.d. ${ }^{1}$ & n.d. & n.d. & n.d. \\
Proline & 0.42 & 0.19 & 0.12 & 0.24 & $0.40-0.48$ \\
Glycine & 0.85 & 0.60 & 0.44 & 0.86 & $0.18-0.24$ \\
Alanine & 0.31 & 0.72 & 0.47 & 0.63 & $0.46-0.52$ \\
Citrulline & 0.03 & tr. ${ }^{2}$ & 0.03 & 0.04 & tr. -0.04 \\
Valine & 0.24 & 0.14 & 0.11 & 0.23 & $0.32-0.35$ \\
Methionine & 0.14 & 0.01 & 0.02 & 0.02 & $0.03-0.05$ \\
Isoleucine & 0.09 & 0.02 & 0.03 & 0.06 & $0.08-0.12$ \\
Leucine & 0.14 & 0.12 & 0.07 & 0.16 & $0.14-0.22$ \\
Tyrosine & 0.08 & 0.03 & 0.03 & 0.04 & $0.11-0.21$ \\
Phenylalanine & 0.08 & 0.11 & 0.06 & 0.11 & $0.06-0.12$ \\
Ornithine & 0.10 & 0.30 & 0.23 & 0.40 & $0.07-0.10$ \\
Lysine & 0.29 & 0.18 & 0.09 & 0.17 & $0.21-0.34$ \\
Histidine & 0.10 & 0.09 & 0.10 & 0.18 & $0.05-0.08$ \\
Arginine & 0.12 & n.d. & tr. & tr. & $0.04-0.10$ \\
\hline
\end{tabular}

${ }^{1}$ n.d. $=$ not detected

${ }^{2}$ tr. $=<0.01 \mu \mathrm{mole} / \mathrm{ml}$. 
Table 2. Urinary excretion of organic acids

\begin{tabular}{ccccc}
\hline $\begin{array}{c}\text { Age } \\
\text { (days) }\end{array}$ & $\begin{array}{c}\text { Ethylmalonic } \\
(\mathrm{mg} / \mathrm{mg} \text { creati- } \\
\text { nine) }\end{array}$ & $\begin{array}{c}\text { Glutaric (mg/ } \\
\text { mg creatinine) }\end{array}$ & $\begin{array}{c}\alpha \text {-hydroxy-glu- } \\
\text { taric }(\mathrm{mg} / \mathrm{mg} \\
\text { creatinine) }\end{array}$ & $\begin{array}{c}\text { Isovaleryl-gly- } \\
\text { cine (n.d }{ }^{1}- \\
++++)\end{array}$ \\
\hline 12 & 0.7 & 0.1 & 3.0 & + \\
19 & n.d. & 26.1 & 10.8 & ++++ \\
37 & 0.1 & 0.2 & 2.2 & ++ \\
44 & 0.5 & n.d. & 4.4 & n.d. \\
47 & 1.9 & 0.4 & 4.7 & n.d. \\
48 & 1.2 & 0.2 & 4.4 & + \\
49 & 0.5 & 0.1 & 3.5 & ++ \\
51 & 0.3 & 0.3 & 2.9 & + \\
52 & 0.3 & 0.2 & 5.8 & n.d. \\
53 & 1.6 & tr. & n.d. \\
55 & 0.9 & tr. & 5.5 & n.d. \\
61 & 0.4 & 0.1 & 2.6 & ++ \\
77 & 0.9 & 0.1 & 3.5 & + \\
91 & 0.4 & tr. & 2.2 & n.d. \\
105 & 0.6 & 0.1 & 2.2 & n.d. \\
126 & 0.8 & n.d. & 3.0 & n.d.
\end{tabular}

'n.d. $=$ not detected

${ }^{2}$ tr. $=<0.1 \mathrm{mg} / \mathrm{mg}$ creatinine

\section{ENZYME STUDIES}

Activity of glutaryl-CoA dehydrogenase in cultured fibroblasts of the patient was $5.89 \mathrm{nmol} \mathrm{CO}_{2} / \mathrm{hr} \mathrm{mg}$ protein in the presence of $0.1 \times 10^{-3} \mathrm{M}$ FAD (normal $=1.90-6.18 ; \mathrm{n}=20$ ) and in its absence was 1.16 , i.e., $20 \%$ of FAD-supplemented activity. In two control lines assayed simultaneously, activity without FAD was 30 and $35 \%$ of that observed when FAD was present. Further investigations on these cells were not possible as the cells did not survive storage in liquid nitrogen.

Table 3 shows activities of glutaryl-CoA dehydrogenase and glutamate dehydrogenase, a mitochondrial marker, in frozen tissues of the patient and three control subjects. Glutaryl-CoA dehydrogenase activity was not detected in liver and was extremely low in kidney; control values show that this deficiency cannot be accounted for by storage for 5 months at $-20^{\circ}$. Activity was not restored by acetone extraction or dialysis; dialysis reduced the activity in normal liver by $50 \%$. When patient and control sonicates were mixed, activity was within $3 \%$ of predicted. Activity was not restored by 10 -fold increases in either glutaryl-CoA or FAD.

Table 4 shows the incorportion of radioactivity from D-(2${ }^{14} \mathrm{C}$ )riboflavin into FMN and FAD by homogenates of kidney from the patient and three control subjects; all tissues had been at $-20^{\circ}$ for comparable periods. There is no obvious difference in incorporation of radiolabel between test and control tissues.

\section{DISCUSSION}

The similarity of the clinical course (early onset of metabolic acidemia and severe hypoglycemia), autopsy findings, and the organic acid excretion pattern to that observed in the only reported patient with glutaric aciduria type II suggests that the child described in this communication had the same or a closely related disorder. A similar disease, albeit with an earlier fatal outcome, in a previous female sibling of the present patient suggests that the disorder is inherited and, if so, that it is transmitted as an autosomal recessive trait.

The abnormal serum and urine amino acids noted in the initial case report were not observed. However, the abnormalities noted in that child are not specific, having been observed in Reye's syndrome $(16,19,27)$, and their relation to the child's then moribund state cannot be evaluated. In our patient, aside from transient elevations of sarcosine in serum and urine, serum amino acids were consistent with intravenous administration of amino

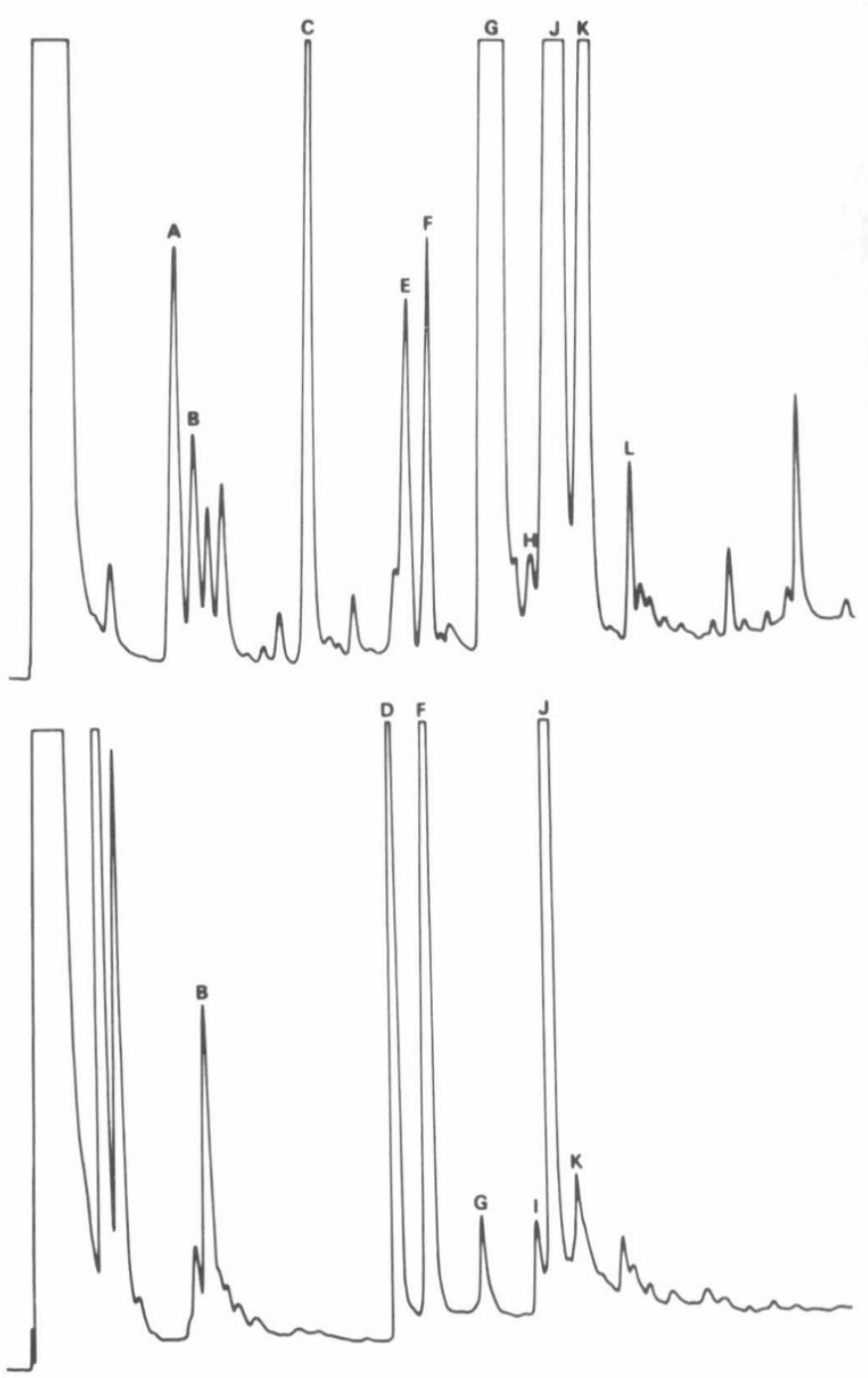

Fig. 1. GC tracings of urine organic acids at 19 (top) and 61 (bottom) days of age. Peaks noted are $A, \alpha$-hydroxyisobutyric; $B$, lactic; $C, \beta$ hydroxy-isovaleric; $D$, ethylmalonic; $E$, urea; $F$, succinic + methylsuccinic; $G$, glutaric; $H$, isobutyrylglycine (monoTMS); $I$, adipic; $J, \alpha$-hydroxyglutaric; $K$, isovalerylglycine (monoTMS); $L, \rho$-hydroxyphenylacetic. Small amounts of $\alpha$-methylbutyrylglycine were detected by MS in the peak of isovalerylglycine on day 19, and large amounts of isobutyrylglycine (diTMS) were present in the descending arm of the glutaric acid peak.

Table 3. Enzyme activity in tissues

\begin{tabular}{|c|c|c|c|c|}
\hline & \multicolumn{3}{|c|}{ Glutaryl-CoA dehydrogenase ${ }^{1}$} & \multirow{2}{*}{$\begin{array}{c}\begin{array}{c}\text { Glutamate } \\
\text { dehydro- } \\
\text { genase }^{2}\end{array} \\
\text { Liver }\end{array}$} \\
\hline & $\begin{array}{c}\text { Liver } \\
\text { sonicate }\end{array}$ & $\begin{array}{l}\text { Liver } \\
\text { acetone } \\
\text { extr. }\end{array}$ & $\begin{array}{l}\text { Kidney } \\
\text { sonicate }\end{array}$ & \\
\hline Control $\left(18^{3}\right)$ & 29.1 & & & 0.08 \\
\hline Control (5) & 93.4 & 92.1 & 55.8 & 0.32 \\
\hline Control (4) & 106.0 & & 83.4 & 0.39 \\
\hline Patient (5) & 0 & 0 & 0.02 & 0.11 \\
\hline
\end{tabular}

\footnotetext{
${ }^{1}$ nmoles $\mathrm{CO}_{2} / \mathrm{hr} / \mathrm{mg}$ protein.

${ }^{2} \mu$ moles NADH oxidized $/ \mathrm{min} / \mathrm{mg}$ protein.

${ }^{3}$ Months at $-20^{\circ}$.
}

acids (9) on one occasion (day 23) and with severe restriction of protein intake (28) on others (days $42,56,63$ ) and urine amino acids were normal.

Sarcosinemia of the amount noted, i.e., $0.140 \mu \mathrm{mole} / \mathrm{ml}$, has 
been observed in hypersarcosinemia and after oral loads of sarcosine $(100 \mathrm{mg} / \mathrm{kg})$ to normal subjects $(7,26)$. Sarcosine is not a component of the amino acid solution infused into this child, nor is sarcosinemia and/or sarcosinuria a usual finding during parenteral hyperalimentation $(9,14)$. Hypersarcosinemia is apparently due to inherited deficiency of sarcosine dehydrogenase (sarcosine: $\mathrm{O}_{2}$ oxidoreductase; E.C. 1.5.3.1), a mitochondrial enzyme responsible for oxidative demethylation of sarcosine to glycine, and the phenotype is quite variable. Some patients have been described with a course similar to that described herein, whereas other individuals have been normal (8).

Organic acids excreted in severe ketosis, i.e., lactic, $\beta$-hydroxybutyric, adipic, suberic, and sebacic (23), were prominent in the initial patient reported but not in the present case; other than this, however, the organic aciduria is much the same (Fig. 2). The glycine conjugates of isovaleric, isobutyric, and $\alpha$-methylbutyric acids suggest blocks in the metabolism of isovaleryl-CoA (leucine), isobutyryl-CoA (valine), and $\alpha$-methylbutyryl-CoA (isoleucine); $\beta$-hydroxyisovaleric and $\alpha$-hydroxyisobutyric acids might be products of $(\omega-1)$-oxidation of isovaleric and isobutyric, and methylsuccinic might derive from $\omega$-oxidation of either isovaleric or $\alpha$ methylbutyric. Gultaric aciduria indicates a block in glutaryl-CoA oxidation (lysine, tryptophan, and hydroxylysine), and ethylmalonic aciduria suggests that fatty acid oxidation is blocked at butyryl-CoA (34). Although ethylmalonic acid can also be pro-

Table 4. Incorporation of $D-\left(2-{ }^{14} C\right)$ riboflavin into $F M N$ and $F A D$ by kidney homogenates

\begin{tabular}{lcc}
\hline & FMN-c.p.m. & FAD-c.p.m. \\
\hline Control & 117,572 & 1768 \\
Control & 50,524 & 1700 \\
Control & 86,632 & 4760 \\
Patient & 119,680 & 4964 \\
\hline
\end{tabular}

duced from $\alpha$-methylbutyric via ethylhydracrylic (22), its absence from urine only during a period of no lipid intake, i.e., parenteral hyperalimentation, suggests that derivation from butyryl-CoA is more likely.

The blocks in acyl-CoA metabolism, whatever their cause, are appreciable. For instance, glutaric acid excretion at diagnosis (26 $\mathrm{mg} / \mathrm{mg}$ creatinine) was $50 \%$ greater than that noted in a completely glutaryl-CoA dehydrogenase-deficient child (12) after a lysine load, and the amounts of $\beta$-hydroxyisovaleric acid and isovalerylglycine were comparable to what is observed in isolated deficiency of isovaleryl-CoA dehydrogenase (14, 30, 31). Further, urine ethylmalonic acid $(0.06-1.9 \mathrm{mg} / \mathrm{mg}$ creatinine $)$ is comparable in amount to that observed in human hypoglycin ingestion $(32,34)$ and in a disorder attributed to isolated deficiency of butyryl-CoA dehydrogenase (33).

The acyl-CoA esters whose metabolism is apparently blocked are all synthesized in mitochondria; isovaleryl-CoA, isobutyrylCoA, $\alpha$-methylbutyryl-CoA, and glutaryl-CoA by oxidative decarboxylation of $\alpha$-ketoacids and butyryl-CoA by thiolase-catalyzed cleavage of $\beta$-ketohexanoyl-CoA. Oxidation of these esters also occurs in mitochondria, but possibly in a different compartment. For instance, branched-chain keto-acid dehydrogenases are situated on the outer surface of the inner mitochondrial membrane (18) and oxidation of the acyl-CoA products occurs in the matrix, on the opposite side of the membrane. Appreciable quantities of the carnitine esters of isovaleric, isobutyric, $\alpha$-methylbutyric, and butyric acids have been found in mammalian heart, liver, and muscle, in accord with the possibility that a membrane is traversed between formation of the CoA esters and their oxidation $(3,5)$.

The first oxidative step for all these acyl-CoA esters is dehydrogenation, and each may have its own specific FAD-dependent dehydrogenase. There is genetic evidence that isovaleryl-CoA dehydrogenase and glutaryl-CoA dehydrogenase are separate and distinct from butyryl-CoA dehydrogenase and, because isobutyryl-CoA and $\alpha$-methylbutyryl-CoA are poor substrates for the

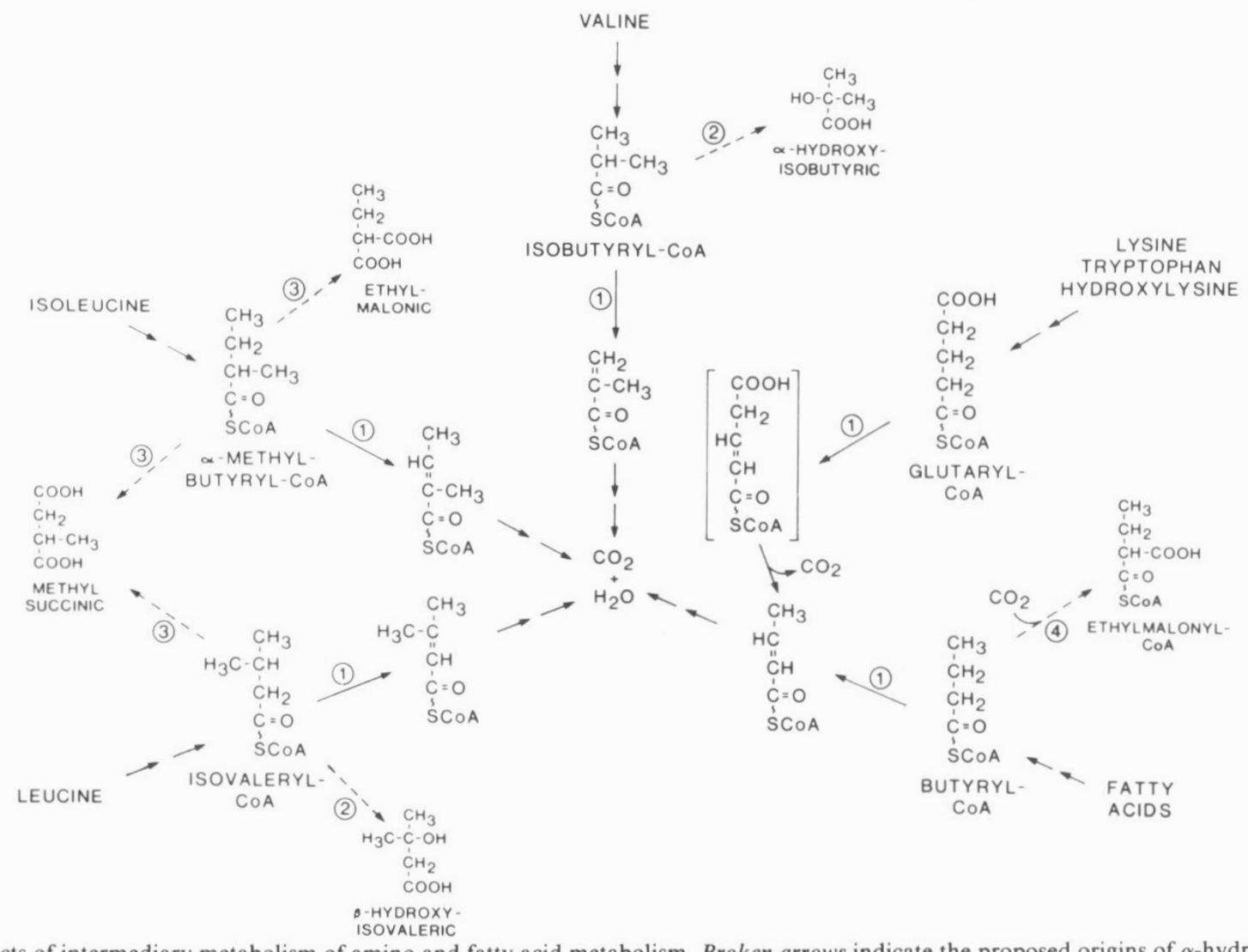

Fig. 2. Aspects of intermediary metabolism of amino and fatty acid metabolism. Broken arrows indicate the proposed origins of $\alpha$-hydroxyisobutyric, ethylmalonic, methylsuccinic, and $\beta$-hydroxyisovaleric acids. (1) acyl-CoA dehydrogenase, (2) ( $\omega$-1)-oxidation, (3) $\omega$-poxidation, (4) carboxylation (propionyl-CoA carboxylase). 
latter (1), their oxidation may require the presence of yet other enzyme(s). Dehydrogenation of the acyl-CoA esters is accompanied by reduction of apoenzyme-bound FAD to FAD.2H, from which electrons pass into the electron transport chain. An electron transfer flavoprotein is intermediate between the FAD of butyrylCoA dehydrogenase and coenzyme $\mathrm{Q}$ of the respiratory chain, and the same electron transfer flavoprotein transfers electrons from the FAD of sarcosine dehydrogenase (17). The site of entry of electrons from the FAD of other acyl-CoA dehydrogenases is not known, but is assumed to be the same.

Possible causes of the many enzyme deficiencies apparently present in this condition thus include (1) mutation of a protein subunit common to acyl-CoA and sarcosine dehydrogenases, (2) defective synthesis of FAD, the common coenzyme, (3) enzyme inhibition, (4) a defect in intercompartmental transfer of acyl-CoA esters, and (5) deficient recycling of apoenzyme-bound FAD.2H.

There is no evidence that acyl-CoA (and sarcosine) dehydrogenase share a common subunit, but the subunit structure of most of these enzymes has not been elucidated and the existence of such a protein can, thus, not be excluded. However, activity of glutaryl-CoA dehydrogenase in fibroblasts of the patient was normal indicating that, unless the subunit is present in some tissues and not in others, mutation of a common protein is not responsible for the disorder.

A generalized defect in FAD synthesis is apparently excluded as the cause of this disorder, since normal incorporation of D-(2${ }^{14} \mathrm{C}$ )riboflavin into FMN and FAD by frozen kidney and normal fibroblast activity of glutaryl-CoA dehydrogenase in the absence of added FAD indicates that FAD is synthesized normally in these tissues. The failure of FAD to restore glutaryl-CoA dehydrogenase activity to enzyme-deficient tissues (liver and kidney) supports this contention. (The authors have also examined fibroblasts from the original patient with glutaric aciduria type II (14, 36). Glutaryl-CoA dehydrogenase activity is normal with and without added FAD, morphology and enzyme activity are no more sensitive to riboflavin-deficient medium than other cell lines, and the cells incorporate $\mathrm{D}-\left(2-{ }^{14} \mathrm{C}\right)$ riboflavin in the medium into FMN and FAD normally. These data suggest that the defect in that patient was likewise not one of FAD synthesis.)

It is also unlikely that the glutaryl-CoA dehydrogenase deficiency noted in liver (and kidney) is due to enzyme inhibition, unless the inhibitor is extremely tightly bound or inhibition is accompanied by enzyme destabilization. Enzyme activity was not restored to liver by acetone extraction, dialysis, or by increasing the substrate concentration, nor did mixing experiments indicate the presence of an inhibitor. Further, the identity of such an inhibitor is not readily apparent. No unusual drugs were given after or immediately before birth, and amino and organic acid analysis provide no obvious suspects. Methylsuccinyl-CoA and ethylmalonyl-CoA are poor inhibitors of glutaryl-CoA dehydrogenase; they inhibit the enzyme very little in the presence of FAD and, in its absence, by only $30-40 \%$ even when their concentrations are 3-4 times the $0.1 \times 10^{-3} \mathrm{M}$ concentration of glutaryl-CoA (14).

The possibility that the organic aciduria is due to failure of certain acyl-CoA esters to traverse membrane barriers, such as might be caused by a mutation of carnitine acyltransferase on the inner mitochondrial membrane, cannot be excluded. Indeed, nonparallel purification of carnitine transferases for acetyl-CoA and isobutyryl-CoA in pigeon breast has suggested the existence of transferases specific for C4-5 acyl-CoA esters (4). This possibility is consistent with normal glutaryl-CoA dehydrogenase activity in disrupted fibroblasts, but does not easily accommodate either the enzyme deficiency noted in frozen tissues or the hypersarcosinemia and sarcosinuria.

The organic aciduria is also consistent with a defect in recycling apoenzyme-bound FAD. $2 \mathrm{H}$, i.e., with a defect in the transfer of electrons into and through the electron transport chain. In view of the central location of this process, survival might not be possible with such a defect unless it were incomplete or involved a component not in the mainstream of electron transport. A defect in the flavoprotein which transfers electrons from the FAD of sar- cosine and acyl-CoA dehydrogenases to coenzyme Q is an obvious possibility, particularly as it accounts for simultaneous accumulation of organic acids and sarcosine. Normal in vitro activity of glutaryl-CoA dehydrogenase in fibroblasts is consistent with this defect because FAD is recycled by methylene blue in the assay used. Again, the apparent deficiency of glutaryl-CoA dehydrogenase in frozen tissue is not easily explained unless it is due to enzyme destabilization, perhaps by reduced FAD.

Insofar as none of the previously mentioned theories can satisfactorily account for glutaryl-CoA dehydrogenase deficiency in frozen liver and kidney, none is wholely acceptable. Further, none of them explains the profound $\alpha$-hydroxyglutaric aciduria which has been present in both patients and which, in our experience, is distinctly unusual. A possible source is reduction of $\alpha$-ketoglutarate behind secondary inhibition of $\alpha$-ketoglutarate dehydrogenase but, if so, the identity of the inhibitor is not obvious; long-chain acyl-CoA esters inhibit this enzyme but short-chain acyl-CoA esters do not (21). On balance, however, the authors believe that the biochemical findings are most consistent with a defect in the flavoprotein which transfers electrons from the FAD of sarcosine and acyl-CoA dehydrogenases into the respiratory chain, although a defect in the intercompartmental transfer of C4-5 acyl-CoA esters is not excluded. Whatever the defect, the excretion of glutaric and other organic acids in this disorder is extremely variable, perhaps depending mainly on the amounts of dietary protein and fat. It appears, therefore, that glutaric aciduria type II is not an appropriate name for this condition and it is suggested that, pending the elucidation of the primary defect, it be replaced by multiple acyl-CoA dehydrogenase deficiency.

\section{REFERENCES AND NOTES}

1. Beinert, H.: Acyl coenzyme A dehydrogenases. In: P. D. Boyer, H. Lardy, K. Myrbäck: The Enzymes. Vol. 7 (Academic Press, New York, 1963) pp. 447466.

2. Besrat, A., Polan, C. E., and Henderson, L. M.: Mammalian metabolism of glutaric acid. J. Biol.Chem., 244: 1461 (1969).

3. Bieber, L. L., and Choi, Y. R.: Isolation and identification of aliphatic shortchain acylcarnitines from beef heart; possible role for carnitine in branchedchain amino acid metabolism. Proc. Natl. Acad. Sci. USA, 74: 2795 (1977).

4. Bieber, L. L.: Unpublished observations (1978).

5. Choi, Y. R., Fogle, P. J., Clarke, P. R. H., and Bieber, L. L.: Quantitation of water-soluble acylcarnitines and carnitine acyltransferase in rat tissues. J. Biol. Chem., 252: 7930 (1977).

6. Fazekas, A. G.: Chromatographic and radioisotopic methods for the analysis of riboflavin and the flavin coenzymes. In: R. S. Rivlin: Riboflavin. (Plenum Press, New York, 1975) pp. 81-98.

7. Gerritsen, T., and Waisman, H. A.: Hypersarcosinemia: An inborn error of metabolism. N. Engl. J. Med., 275: 66 (1966).

8. Gerritsen, T., and Waisman, H. A.: Hypersarcosinemia. In: J. B. Stanbury, J. B. Wyngaarden, and D. S. Fredrickson: The Metabolic Basis of Inherited Disease. 4th Edition (McGraw-Hill, New York, 1978) pp. 514-517

9. Ghadimi, H., Abaci, F., Kumar, S., and Rathi, M.: Biochemical aspects of intravenous alimentation. Pediatrics, 48: 955 (1971).

10. Goodman, S. I., and Hammond, K. B.: The detection of pathological organic aciduria In: A. Dorfman: Antenatal Diagnosis. (University of Chicago Press, Chicago, 1972) pp. 127-135.

11. Goodman, S. I., and Kohlhoff, J. G.: Glutaric aciduria: inherited deficiency of glutaryl-CoA dehydrogenase actvity. Biochem. Med., 13: 138 (1975).

12. Goodman, S. I., Markey, S. P., Moe, P. G., Miles, B. S., and Teng, C. C.: Glutaric aciduria: A "new" disorder of amino acid metabolism. Biochem. Med., 12: 12 (1975).

13. Goodman, S. I., Norenberg, M. D., Shikes, R. H., Breslich, D. J., and Moe, P. G.: Glutaric aciduria: biochemical and morphologic considerations. J. Pediatr., 90: 746 (1977).

14. Goodman, S. I.: Unpublished observations (1978).

15. Gregersen, N., Brandt, N. J., Christensen, E., Grøn, I., Rasmussen, K., and Brandt, S.: Glutaric aciduria; clinical and laboratory findings in two brothers. J. Pediatr., 90: 740 (1976).

16. Hilty, M. D., Romshe, C. A., and Delamater, P. V.: Reye's syndrome and hyperaminoacidemia. J. Pediatr., 84: 362 (1974)

17. Hoskins, D. D.: The electron-transferring flavoprotein as a common intermediate in the mitochondrial oxidation of butyryl coenzyme A and sarcosine. J. Biol. Chem., 241: 4472 (1966).

18. Johnson, W. A., and Connelley, J. L.: Cellular localization and characterization of bovine liver branched-chain $\alpha$-keto acid dehydrogenases. Biochemistry, 11 : 1967 (1972).

19. Kang, E. S. and Gerald, P. S.: Hyperammonemia and Reye's syndrome. N. Engl. J. Med., 286: 1216 (1972).

20. Kyllerman, M., and Steen, G.: Intermittently progressive dyskinetic syndrome in glutaric aciduria. Neuropädiatrie, 8: 397 (1977). 
21. Lenartowicz, E., and Olson, M. S.: The inhibition of $\alpha$-ketoglutarate oxidation by fatty acids in rat liver mitochondria. J. Biol. Chem., 253: 5990 (1978).

22. Mamer, O. A., and Tjoa, S. S.: 2-Ethylhydracrylic acid: a newly described urinary organc acid. Clin. Chim. Acta, 55: 199 (1974).

23. Pettersen, J. E., Jellum, E., and Eldjarn, L.: The occurrence of adipic and suberi acid in urine from ketotic patients. Clin. Chim. Acta, 38: 17 (1972).

24. Przyrembel, H., Wendel, U., Becker, K., Bremer, H. J., Bruinvis, L., Ketting, D. and Wadman, S. K.: Glutaric aciduria type II: report on a previously undes cribed metabolic disorder. Clin. Chim. Acta, 66: 227 (1976).

25. Schmidt, E.: Glutamic dehydrogenase In: H. U. Bergmeyer: Methods of Enzymatic Analysis. Vol. 2 (Academic Press, New York, 1974) p. 650

26. Scott, C. R., Clark, S. H., Teng, C. C., and Swedberg, K. R.: Clinical and cellular studies of sarcosinemia. J. Pediatr., 77: 805 (1970).

27. Shih, V. E., Glick, T. H., and Bercu, B. B.: Lysine metabolism in Reye's syndrome. Lancet, 2: 163 (1974).

28. Snyderman, S. E., Holt, L. E., Jr., Norton, P. M., Roitman, E., and Phansalkar S. V.: The plasma aminogram, I. Influence of the level of protein intake and a comparison of whole protein and amino acid diets. Pediatr. Res., 2: 131 (1968).

29. Stokke, O., Goodman, S. I., Thompson, J. A., Miles, B. S.: Glutaric Aciduria presence of glutaconic and $\beta$-hydroxyglutaric acids in urine. Biochem. Med., 12: $386(1975)$

30. Tanaka, K., and Isselbacher, K. J.: The isolation and identification of $\mathrm{N}$-isovalerylglycine from urine of patients with isovaleric acidemia. J. Biol.Chem., 242:
2966 (1967).

31. Tanaka, K., Orr, J. C., and Isselbacher, K. J.: Identification of $\beta$-hydroxyisovaleric acid in the urine of a patient with isovaleric acidemia. Biochim. Biophys. Acta, 152: 638 (1968).

32. Tanaka, K., Kean, E. A., and Johnson, B.: Jamaican vomiting sickness: biochemical investigation of two cases. N. Engl. J. Med., 295: 461 (1976).

33. Tanaka, K., Mantagos, S., Genel, M., Seashore, M. R., Billings, B. A., and Baretz, B. H.: New defect in fatty acid metabolism with hypoglycaemia and organic aciduria. Lancet, 2: 986 (1977).

34. Tanaka, K., Ramsdell, H. S., Baretz, B. H., Keefe, M. B., Kean, E. A., and Johnson, B.: Identification of ethylmalonic acid in urine of two patients with the vomiting sickness of Jamaica. Clin. Chim. Acta, 69: 105 (1976)

35. Full and informed consent for the studies on this child was obtained from the parents.

36. The authors thank Dr. H. Bremer for providing us with fibroblasts from the patient described in Reference 24 and G. Kohlhoff, H. McKelvey and B. S. Miles for expert technical assistance.

37. This research was supported by Maternal and Child Health Special Project 252 and by National Institutes of Health grant HD-04024.

38. Requests for reprints should be addressed to: Dr. Stephen I. Goodman, Department of Pediatrics, Box C-233 University of Colorado Medical Center, 4200 East Ninth Avenue, Denver, Colorado 80262.

39. Received for publication June 20, 1978.

40. Accepted for publication January 30, 1979. 